\author{
Research Article \\ www.ijrap.net
}

\title{
COMPARATIVE ANALYTICAL STANDARDS OF TAMRADI TAILA AND \\ ITS MODIFIED CREAM FORM
}

B. Vinaya Chandra Shetty ${ }^{* 1}$, Sooraj V.K ${ }^{2}$

${ }^{1}$ Principal and Professor, Alvas Ayurveda Medical College, Moodbidri, D.K, District, Karnataka, India

${ }^{2}$ PG Scholar, Alvas Ayurveda Medical College, Moodbidri, D.K, District, Karnataka, India

Received on: 01/11/16 Revised on: 28/11/16 Accepted on: 20/12/16

\author{
*Corresponding author \\ E-mail: kaupviraj@gmail.com
}

DOI: $10.7897 / 2277-4343.076238$

\begin{abstract}
Tamra is being used internally in the form of bhasma (residue after incineration) extensively. Tamra in the form of choorna (powder) is used in the preparation of Taila and is used externally. Tamradi Taila has been explained as one of the most effective medicine for the treatment of Vyanga (Melasma) in Ayurveda classics. Though the formulation is useful, its form poses certain inconveniences. Keeping these points in view the present study has been undertaken with the aim to modify Tamradi taila yoga into Cream form and to develop the physico-chemical profile of the product. Tamradi Taila Cream prepared by principle of Emulsification. The prepared Tamradi taila and Tamradi Cream was evaluated for organoleptic parameters, physico-chemical profiles like pH, loss on drying, Rancidity, Refractive index and Saphonification value, also the product was subjected for and HPTLC profiles. It was inferred from the results that Organoleptic parameters and Physico-chemical profile of the product were in the acceptable range, HPTLC profile revealed the presence of 6 spots under $254 \mathrm{~nm}$ and $366 \mathrm{~nm}$ respectively for Tamradi taila and 8 spots each in $254 \mathrm{~nm}$, $366 \mathrm{~nm}$ for Tamradi taila cream. Till date no analytical standards established for this modified formulation, hence this analytical profile may serve for future studies and to maintain standard quality of the formulation
\end{abstract}

Keywords: Tamra, Vyanga, Tamradi Taila, Tamradi Cream

\section{INTRODUCTION}

Rasasashtra is one of the very important offshoots of Ayurveda which mainly deals with above mentioned substances. Rasoushadhis (Mercurial preparations) have attributes like instant effectiveness, requirement in very small doses and extensive therapeutic utility which help in Deha siddhi (Enhance body health). Tamradi Taila has been explained as one of the most effective medicine for the treatment of Vyanga (Melasma) in Rajamarthanda ${ }^{1}$ and Bharata Bhaishajya Ratnakara ${ }^{2}$. Physicochemical and Analytical study provides the objective parameters to fix up the standards for quality of raw drugs as well as finished products. Classical texts of Ayurveda have mentioned analytical techniques to understand the quality of the end product. These are mostly qualitative and subjective. Modern analytical techniques can be applied to the product to ascertain its components which also gives an idea of its pharmacological action. Skin responds better to natural products than synthetic ones and this explains the latest trend of using traditional, natural products in dermatological formulation. In the present study Tamradi taila is prepared classically and is modified in to $\mathrm{cream}^{3}$ form, for easy handling and use and a comparative analytical standards were analysed.

\section{MATERIALS AND METHODS}

Major Drugs: Tamra patra (Copper foil), Tila Taila (Gingelly oil), Godugdha, (Cow's milk), Kesara (Crocus sativus) are the major ingredients in the preparation of Taila. Stearic acid, Triethanolamine, Lanolin, Distilled water, Glycerin are the raw drugs in the preparation of Cream. These materials were collected from authentic sources according to the Grahya Agrahya Lakshnas, (Quantitative and Qualitative analysis)
Associated Drugs: The other raw materials used for the present study are Saindava lavana (Rock salt) Nimbu Swarasa (Lemon extract) and Nirgundi swarasa (Vitex nigundo extract) for Shodhana of Tamra. Tankana pisti (Borax paste) and Gomutra (Cow's urine) for preparation of Tamra choorna, (Copper powder).

Analytical tests were carried out at SDM Center for Research in Ayurveda \& Allied Sciences, Udupi, Karnataka, India.

\section{Organoleptic characters}

Organoleptic characters of the test sample were documented by means of examination using sensory organs.

\section{Loss on drying at $105^{\circ} \mathrm{C}$}

$10 \mathrm{~g}$ of sample was placed in tarred evaporating dish. It was dried at $105{ }^{\circ} \mathrm{C}$ for 5 hours in hot air oven and weighed. The drying was continued until difference between two successive weights was not more than 0.01 after cooling in desiccator. Percentage of moisture was calculated with reference to weight of the sample. ${ }^{4}$

\section{Rancidity test}

$1 \mathrm{ml}$ of melted fat was mixed with $1 \mathrm{ml}$ of conc. $\mathrm{HCl}$ and $1 \mathrm{ml}$ of $1 \%$ solution of phloroglucinol in diethyl ether and then mixed thoroughly with the fat acid mixture. A pink color indicates that the fat is slightly oxidized while a red color indicates that the fat is definitely oxidized. ${ }^{5}$ 


\section{Refractive index}

Placed a drop of water on the prism and adjusted the drive knob in such a way that the boundry line intersects the separatrix exactly at the centre. Reading was noted. Distilled water has a refractive index of 1.3325 at $25{ }^{\circ} \mathrm{C}$. The difference between the reading and 1.3325 gives the error of the instrument. If the reading is less than 1.3325 , the error is minus (-) then the correction is plus $(+)$ if the reading is more, the error is plus $(+)$ and the correction is minus (-). Refractive index of oil is determined using 1 drop of the sample. The correction if any should be applied to the measured reading to get the accurate refractive index. Refractive index ${ }^{6}$ of the test samples were measured at $28^{\circ} \mathrm{C}$.

\section{Determination of $\mathrm{pH}$}

Preparation of buffer solutions: Standard buffer solution: Dissolved one tablet of $\mathrm{pH} \mathrm{4,7}$ and 9.2 in $100 \mathrm{ml}$ of distilled water.

Determination of $\mathrm{pH}^{7}: 1 \mathrm{ml}$ of sample was taken and makes up to $10 \mathrm{ml}$ with distilled water, stirred well and filtered. The filtrate was used for the experiment. Instrument was switched on. 30 minutes time was given for warming $\mathrm{pH}$ meter. The $\mathrm{pH} 4$ solution was first introduced and the $\mathrm{pH}$ adjusted by using the knob to 4.02 for room temperature $30{ }^{\circ} \mathrm{C}$. The $\mathrm{pH} 7$ solution was introduced and the $\mathrm{pH}$ meter adjusted to 7 by using the knob. Introduced the $\mathrm{pH} 9.2$ solution and checked the $\mathrm{pH}$ reading without adjusting the knob. Then the sample solution was introduced and reading was noted. Repeated the test four times and the average reading were taken as result.

\section{Determination of Saponification value}

About $2 \mathrm{~g}$ of the substance was weighed in tared $250 \mathrm{ml}$ round bottom flask. $25 \mathrm{ml}$ of the alcoholic solution of $\mathrm{KOH}$ was added and a reflux condenser was attached. Kept it for boiling on water bath for 1hour, the contents of the flask was rotated frequently. The flask was cooled and $1 \mathrm{ml}$ phenolphthalein solution was added and excess of alkali titrated with $0.5 \mathrm{~N} \mathrm{HCl}$. The number of $\mathrm{ml}$ (a) required was noted. The experiment was repeated with the same quantities of reagents in the same manner omitting the substance. The number of $\mathrm{ml}$ required (b) was noted. The experiment was repeated twice to get concordant values.

Saponification value ${ }^{8}=56.1 \times(\mathrm{b}-\mathrm{a}) \times$ Strength of Hydrochloric acid / Weight of the sample taken

\section{Determination of Unsaponifiable matter}

Weighed $5 \mathrm{~g}$ of the substance into the flask. Added $50 \mathrm{ml}$ alcoholic $\mathrm{KOH}$ into the sample. Boiled gently but steadily under reflux condenser for one hour. The condenser was washed with $10 \mathrm{ml}$ of ethyl alcohol and the mixture was collected and transferred to a separating funnel. The transfer was completed by washing the sample with ethyl alcohol and cold water. Altogether, $50 \mathrm{ml}$ of water was added to the separating funnel followed by an addition of $50 \mathrm{ml}$ petroleum ether. The stopper was inserted and shaken vigorously for 1 minute and allowed it to settle until both the layers were clear. The lower layer containing the soap solution was transferred to another separating funnel and repeated the ether extraction six times more using $50 \mathrm{ml}$ of petroleum ether for each extraction. All the extracts were collected in a separating funnel. The combined extracts were washed in the funnel 3 times with $25 \mathrm{ml}$ of aqueous alcohol and shaken vigorously. And drawing off the alcoholwater layer after each washing. The ether layer was again washed repeatedly with $25 \mathrm{ml}$ of water until the water no longer turns pink on addition of a few drops of Phenolphthalein indicator solution. The ether layer was transferred to a tarred flask containing few pieces of pumice stone and evaporated to dryness on a water bath. Placed the flask in an air oven at $85^{\circ} \mathrm{c}$ for about 1 hour to remove the last traces of ether. A few $\mathrm{ml}$ of Acetone was added and evaporated to dryness on a water bath. Cooled in a desicator to remove last traces of moisture and then weighed ${ }^{9}$.

\section{HPTLC}

Unsaponifiable matter of the given sample is dissolved in $10 \mathrm{ml}$ of chloroform. $9 \mu 1$ of the each of the above sample was applied on a precoated silica gel F254 on aluminum plates to a band width of $8 \mathrm{~mm}$ using Linomat 5 HPTLC $^{10}$ applicator, the Linomat 5 company name is Camag made in Switzerland .The plate was developed in Toluene - Ethyl acetate (8: 1)and the developed plates were visualized under 254 and $366 \mathrm{~nm}$ and after derivatisation in vanillin-sulphuric acid spray reagent and scanned under UV $254 \mathrm{~nm}, 366 \mathrm{~nm}$ and $620 \mathrm{~nm}$. $\mathrm{R}_{\mathrm{f}}$, colour of the spots and densitometric scan were recorded.

\section{RESULTS AND DISCUSSION}

The results obtained from the Analytical study were depicted in the tables. The Organoleptic parameters were presented in Table 1. The results of Standardisation parameters were shown in Table 2. Rf values were presented in table 3.The Densitometric scan at $254 \mathrm{~nm}, 366 \mathrm{~nm}, 620 \mathrm{~nm}$ were presented in Figure 2,3 and 4 respectively. Densitometric scsn at $366 \mathrm{~nm}$ following derivitisation presented at Figure 5 and Chromatogram represented at Figure 6.

Quality of a medicine is very important in health care system. Standardization is an essential measurement for ensuring the quality control of the herbal and mineral drugs. Analytical study brings standards for the quality drugs and helps in explaining pharmacokinetics and pharmacodynamics of a drug. Uniform consistency is also a mandatory criterion for topical applications, which can be elicited by rubbing the sample on the back of the hand; no solid components should be noticed. From the data of organoleptic analysis of the both formulations, it is clearly evident all the parameters found to be satisfactory.

$\mathrm{pH}$ of Tamradi taila is 4.7 being slightly acidic, as that of Tamradi cream is 5.5, which lies within the normal $\mathrm{pH}$ of human skin ie between 5- 6.5. But both the formulations did not produce any skin irritation. Previous studies shows that the drug Tamra (Copper) does not produce any toxic effect in experimental models. ${ }^{11}$ Loss on drying is a measure of amount of water and volatile matters in the sample, when the sample is dried under specified condition. Loss on drying of Tamradi cream was found to be 16.15 , reason may be the presence of water soluble components in Tamradi cream. Rancidity usually characterizing fat that is undergoing oxidation or bacterial decomposition. Auto oxidation occurring in natural edible fats is called Rancidification. Both formulations found to be non rancid, since the fat is not oxidized. The Refractive index of Tamradi taila is 1.47 . 
Table 1: Organoleptic characters of the Tamradi Taila and Tamradi Taila cream

\begin{tabular}{|c|c|c|}
\hline Parameter & Tamradi taila & Tamradi cream \\
\hline Colour & Dark greenish & Pale greenish \\
\hline Appearance & Semi solid & Semi solid \\
\hline Odour & Greasy odour & Greasy odour \\
\hline
\end{tabular}

Table 2: Standardisation parameters for Tamradi taila and Tamradi Taila cream

\begin{tabular}{|c|c|c|}
\hline Parameters & Tamradi taila & Tamradi Taila cream \\
\hline LOD & - & 16.15 \\
\hline Rancidity & Fat is not oxidised & Fat is not oxidized \\
\hline Refractive index & 1.4724 & - \\
\hline pH & 4.7 & 5.5 \\
\hline Saponification value & 148.25 & 134.93 \\
\hline Unsaponifiable matter & 10.35 & 9.34 \\
\hline
\end{tabular}

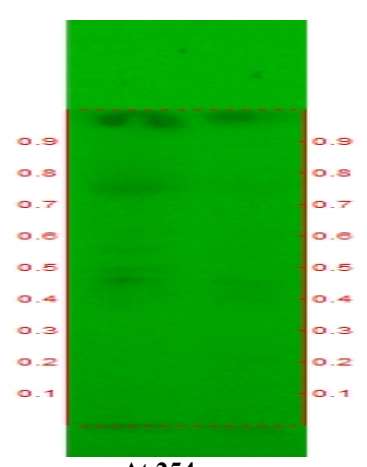

At 254 nm

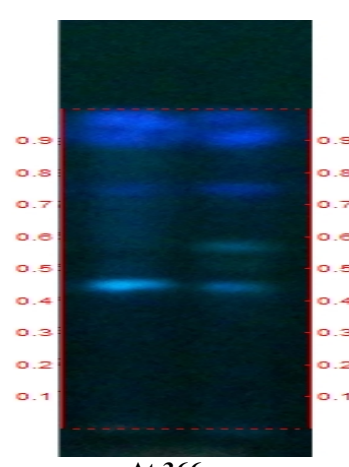

At $366 \mathrm{~nm}$

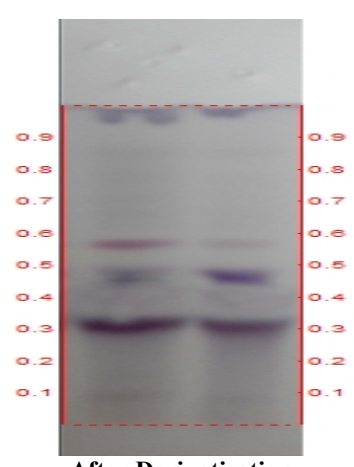

After Derivatisation

Figure 1. HPTLC photo documentation of chloroform extract of Tamradi taila and Tamradi Taila Cream Track 1-Tamraditaila - $9 \mu$ l, Track 2 - Tamradi cream - $9 \mu 1$, Solvent system: Toluene: Ethyl acetate (8:1)

Table 3: $\mathbf{R}_{\mathrm{f}}$ values of Tamradi Taila and Tamradi Taila Cream

\begin{tabular}{|c|c|c|c|c|c|}
\hline \multicolumn{2}{|c|}{ At 254 nm } & \multicolumn{2}{c|}{ At 366 nm } & \multicolumn{2}{c|}{ After Derivatisation } \\
\hline Tamradi taila & Tamradi cream & Tamradi taila & Tamradi cream & Tamradi taila & Tamradi cream \\
\hline- & - & - & - & 0.09 (L. purple) & 0.09 (L. purple) \\
\hline- & - & - & - & 0.16 (L. purple) & - \\
\hline- & 0.22 (L. green) & - & - & - & - \\
\hline- & - & - & - & 0.32 (D. purple) & 0.32 (D. purple) \\
\hline- & - & - & - & 0.40 (L. pink) & - \\
\hline- & - & 0.44 (F. blue) & 0.44 (F. blue) & - & - \\
\hline 0.46 (L. green) & 0.46 (L. green) & - & - & 0.46 (D. purple) & 0.46 (D. purple) \\
\hline 0.50 (L. green) & - & - & - & 0.50 (D. purple) & - \\
\hline- & - & - & 0.53 (FL. blue) & - & - \\
\hline 0.56 (L. green) & - & - & - & - & - \\
\hline- & - & 0.57 (FL. blue) & 0.57 (F. blue) & 0.57 (D. pink) & 0.57 (L. purple) \\
\hline- & - & 0.70 (FL. blue) & - & - & - \\
\hline- & - & - & - & 0.72 (L. purple) & - \\
\hline 0.75 (D. green) & 0.75 (L. green) & 0.75 (FD. blue) & 0.75 (FD. blue) & - & - \\
\hline- & - & - & - & 0.78 (L. purple) & - \\
\hline- & - & - & - & 0.86 (L. purple) & - \\
\hline- & - & 0.92 (FD. blue) & 0.92 (FD. blue) & - & - \\
\hline
\end{tabular}

Tamradi Taila showed 4 spots at $254 \mathrm{~nm}, 5$ spots at $366 \mathrm{~nm}$ and 10 spots at post derivatisation. Tamradi Taila Cream showed 3 spots at $254 \mathrm{~nm}, 5$ spots at $366 \mathrm{~nm}$ and 4 spots at post derivatisation. 


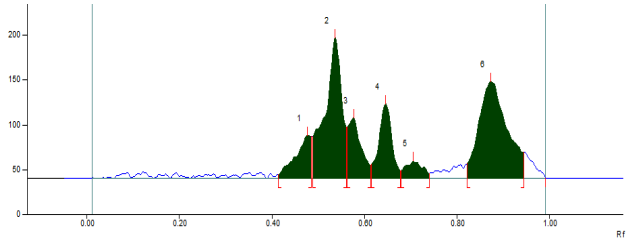

Track 5, ID: Tamradi taila
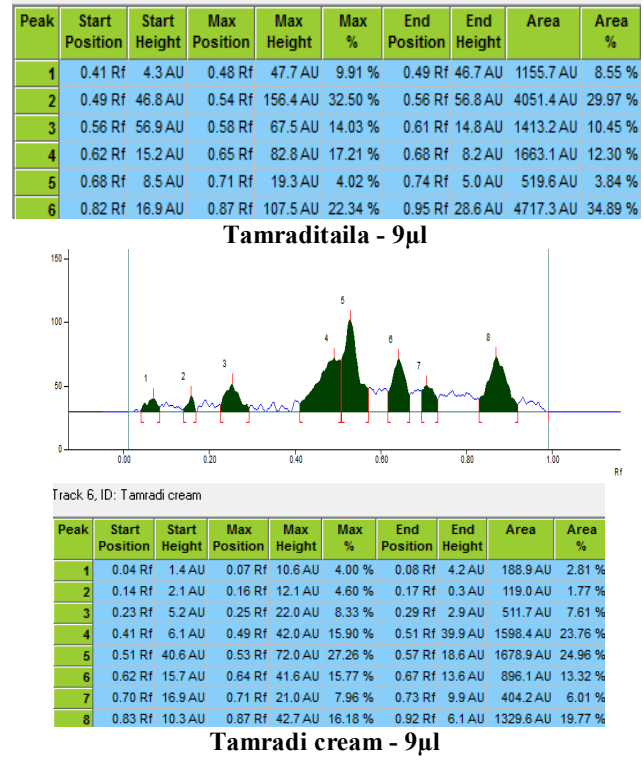

Figure 2: Densitometric scan of the sample at $254 \mathrm{~nm}$
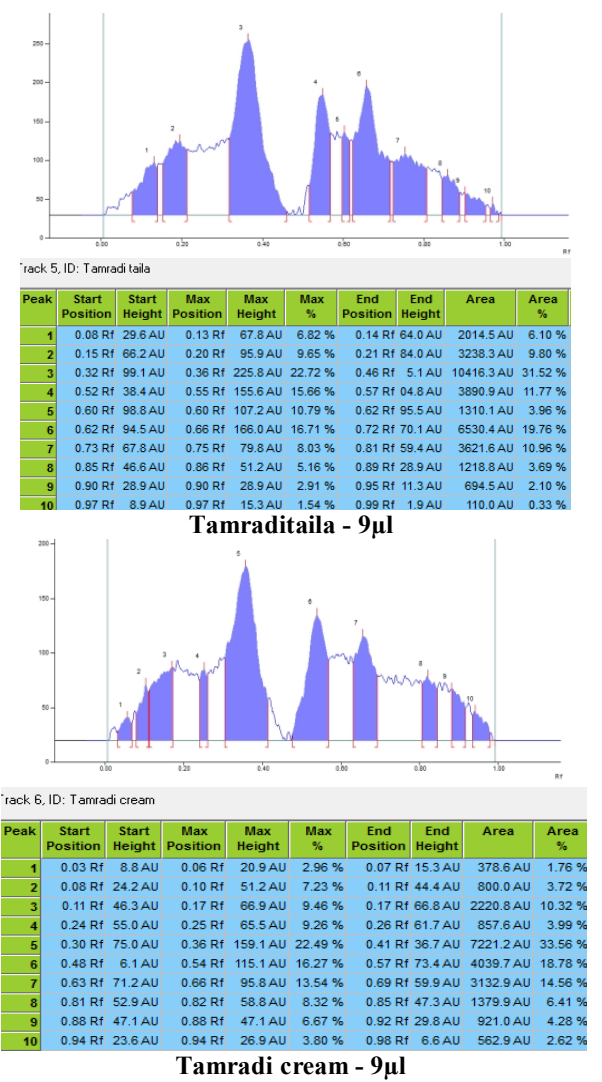

Figure 4: Densitometric scan of the sample at $620 \mathrm{~nm}$ following derivatisation

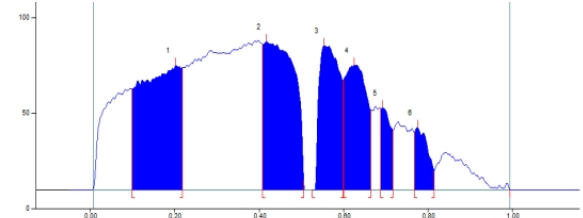

Track 5, ID: Tamradi taila
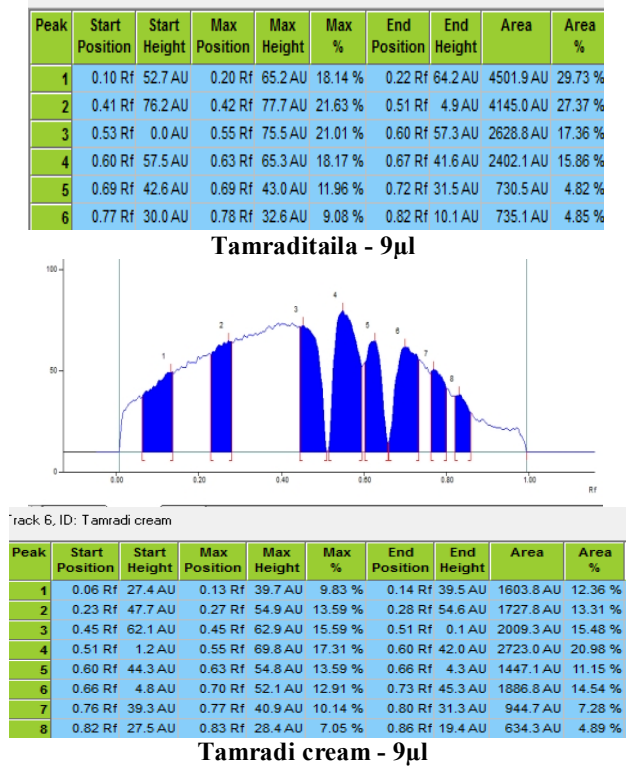

Figure 3: Densitometric scan of the sample at 366nm
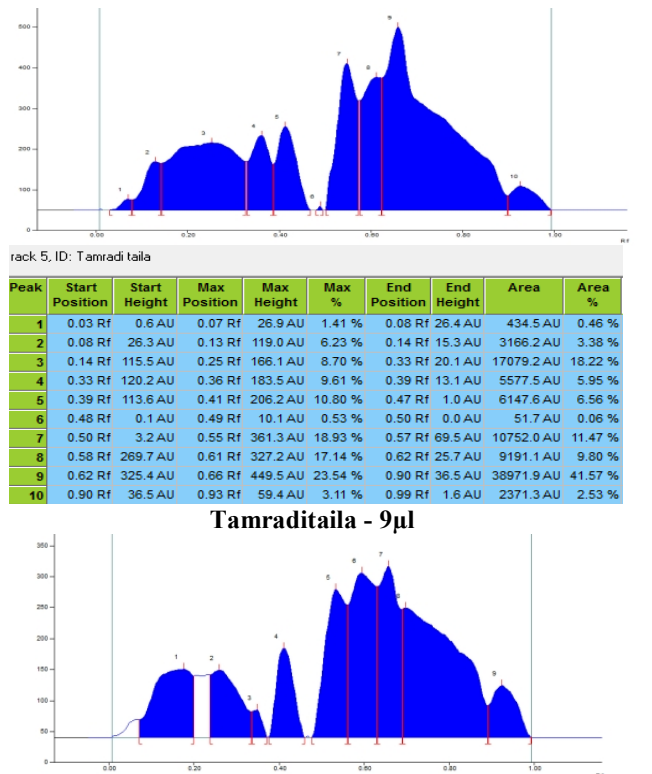

Track 6, ID: Tamradi crean

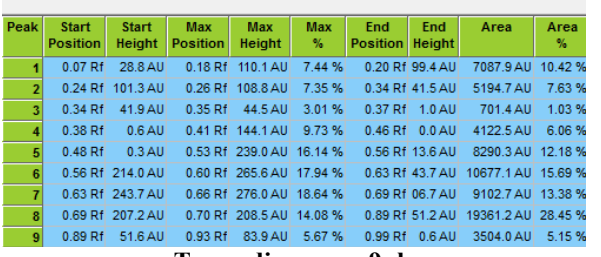

Tamradi cream - 9ul

Figure 5: Densitometric scan of the sample at $366 \mathrm{~nm}$ following derivatisation 


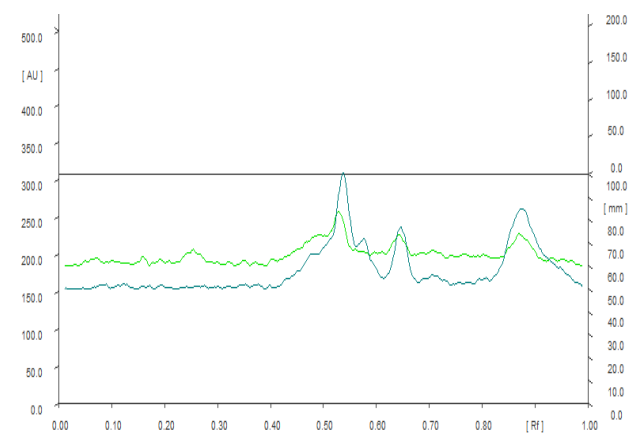

Figure: 6.1 At $254 \mathrm{~nm}$

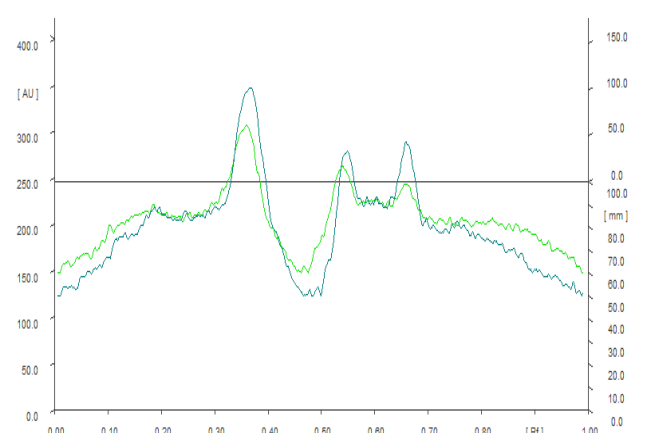

Figure: 6.3 At $620 \mathrm{~nm}$

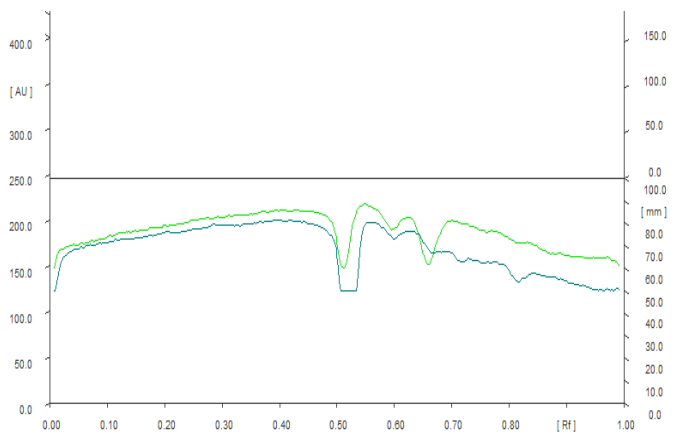

Figure: 6.2 At 366nm

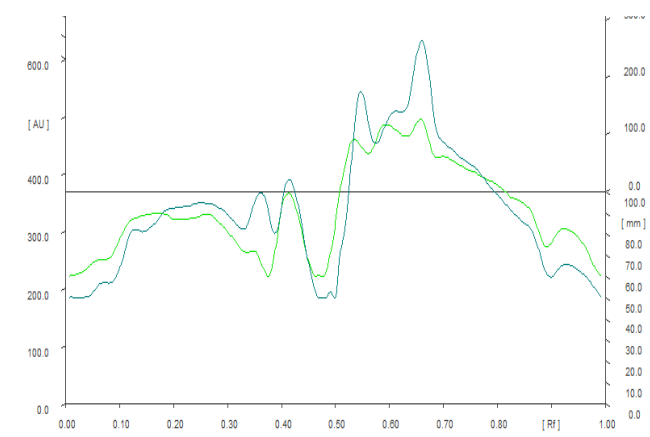

Figure: 6.4 At 366nm after derivitisation

Figure 6: Chromatogram

Medicated oil with high saphonification value has better absorption. High saphonification value also indicates the presence of fatty acids of low molecular weight (molecules are in simple form). Low saphonification value indicates the molecules are in complex form. Tamradi taila got a saphonification value of 148.25 and that of Tamradi cream was 134.93. It indicates the better absorption of Tamradi taila than that of Tamradi cream. Whereas unsaphonification value is 10.34 in Tamradi taila and 9.34 in Tamradi cream. On analyzing the HPTLC results, Densitometric scan at $254 \mathrm{~nm}$ of Tamradi taila showed 6 peaks and under $366 \mathrm{~nm}$, it showed 6peaks. Under $254 \mathrm{~nm}$, Tamradi cream showed 8 peaks, under $366 \mathrm{~nm}$, showed 8 peaks in densitometric scan. From these it can be assessed that more active principles are present in Tamradi cream when compared with Tamradi taila. Spots at $366 \mathrm{~nm}$ were almost matching with each other, indicating presence of similar compounds but not same in case of visualization at $254 \mathrm{~nm}$. The differences indicate the presence of variable functional groups in both the formulations

\section{CONCLUSION}

HPTLC reports revealing more active constituents are present in Tamradi taila compared to Tamradi cream. Saphonification value reveals that Tamradi Taila is having more absorption rate compared to Tamradi Cream .PH of Tamradi Taila is being slightly acidic while PH of Tamradi Taila cream with in the normal ph of skin.Both formulations found to be non rancid, since the fat is not oxidized. The Refractive index of Tamradi taila is 1.47 .

\section{ACKNOWLEDGEMENT}

The authors are thankful to Dr. M. Mohan Alva, Chairman Alva's Ayurveda Medical College and Hospital, Moodbidri, Dr. M.S. Krishnamurthy, HOD and Professor, Dept. of Rasa Shastra and Bhaishajya Kalpan, Dr. Ravi Rao Professor, Dept. of Dravya Guna, Alva's Ayurveda Medical College Moodbidri, and the staffs of SDM Center for Research and Allied Sciences, Udupi, Karnataka for providing facilities to conduct analytical tests and also for their valuable guidance.

\section{REFERENCES}

1. Acharya Vagbhata, Rasaratna Samucchaya, translated and commentary in English by DR.VA.Dole, published by Chaukamba Sanskrit Series Varanasi, second edition 2008, Shloka No : 50, Page No: 181

2. Madhavamadhupadyaya, Ayurvedaprakasa, Vidyodhini hindi commentary, Chaukhamba bharat academy,Varanasi,Shloka No 244,page no 3196.

3. R.M.Metha,Text book of Pharmaceutics ,chapter 10,Cosmetic preparations, Volume 2,p.no 211

4. The Ayurvedic Pharmacopoeia of India, Reprint Edition,2007 New delhi: The Controller of Publications; Part 2, Vol 2 Appendix2.2.10, P.no 161

5. The Ayurvedic Pharmacopoeia of India, Reprint Edition,2007 New delhi: The Controller of Publications; Part 2, Vol 2, Ibid Appendices 3.16,p.no225

6. Lohar, Quality control manuel for Ayurvedic, siddha and unani medicine by Govt. of India, Dept. of Ayush, Ghaziabad. Page no:35 
7. The Ayurvedic Pharmacopoeia of India, Reprint Edition, 2007 New delhi: The Controller of Publications; Part 2, Vol 2 Appendix3.3 , P.no 213.

8. Lohar, Quality control manuel for Ayurvedic, siddha and unani medicine by Govt. of India, Dept. of Ayush, Ghaziabad. Page no:34

9. The Ayurvedic Pharmacopoeia of India, Reprint Edition, 2007 New delhi: The Controller of Publications; Part 2, Vol 2 Appendix3.14, P.no 224

10. The Ayurvedic Pharmacopoeia of India, Reprint Edition, 2007 New delhi: The Controller of Publications; Part 2, Vol 2, Ibid Appendix 2.2.13,p.no.164
11. Honwad Sudheendra V, Toxicity study of Tamra bhasma prepared with various methods Int. J. Res. Ayurveda Pharm 2011; 2(6):1685-1691

\section{Cite this article as:}

B. Vinaya Chandra Shetty, Sooraj V.K. Comparative analytical standards of Tamradi taila and its modified cream form. Int. J. Res. Ayurveda Pharm. Nov - Dec 2016;7(6):45-50 http://dx.doi.org/10.7897/2277-4343.076238

\section{Source of support: Nil, Conflict of interest: None Declared}

Disclaimer: IJRAP is solely owned by Moksha Publishing House - A non-profit publishing house, dedicated to publish quality research, while every effort has been taken to verify the accuracy of the content published in our Journal. IJRAP cannot accept any responsibility or liability for the site content and articles published. The views expressed in articles by our contributing authors are not necessarily those of IJRAP editor or editorial board members. 